\title{
Lipid profile and plasma atherogenic index in postmenopausal osteoporosis
}

\author{
Gulcin Sahin Ersoy, ${ }^{1}$ Engin Ersin Simsek, ${ }^{2}$ Dogan Vatansever, ${ }^{1}$ Halim Omer Kasikci, ${ }^{2}$ \\ Buket Keser, ${ }^{3}$ Onder Sakin ${ }^{1}$ \\ ${ }^{1}$ Department of Obstetrics and Gynecology, Kartal Dr. Lutfi Kırdar Training and Research Hospital, Istanbul, Turkey \\ 2Department of Family Medicine, Kartal Dr. Lütfi Kırdar Training and Research Hospital, Istanbul, Turkey \\ ${ }^{3}$ Department of Obstetrics and Gynecology, Osmaniye State Hospital, Osmaniye, Turkey
}

\begin{abstract}
OBJECTIVE: The goal of this study was to investigate the relationship between the lipid profile, plasma atherogenic index (PAI), and osteoporosis in postmenopausal women.

METHODS: The data of age, duration of menopause, height, weight, lipid profile, bone mineral density (BMD) value, and history of oral contraceptive use of 407 postmenopausal women who had not been menstruating for at least 12 months, were between the ages 45 and 80, and presented at the obstetrics and gynecology polyclinic of Kartal Dr. Lutfi Kirdar Training and Research Hospital were reviewed. The patients were divided into 2 groups according to the presence of osteoporosis, and the data compared. The level of significance was accepted as $\mathrm{p}<0.05$.
\end{abstract}

RESULTS: A total of 142 postmenopausal patients with osteoporosis were included in the study. The mean age was $61.7 \pm 6.9$ years. In the control group, there were 263 postmenopausal women without osteoporosis, with a mean age of $58.3 \pm 4.5$ years. There was no statistically significant difference with respect to triglyceride level; however, in the osteoporosis group, the level of total cholesterol and low-density lipoprotein (LDL) were lower, and the level of high-density lipoprotein (HDL) was higher $(p=0.762, p=0.002, p=0.01, p<0.001$, respectively).

CONCLUSION: A high level of HDL, and low LDL and PAI values, which are important for the prevention of cardiovascular disease, were found to be negative factors for BMD.

Keywords: Lipid profile; plasma atherogenic index; postmenopausal osteoporosis.

$\mathrm{O}$ steoporosis is preventable and treatable, but it is often clinically occult until the development of fracture [1]. Postmenopausal osteoporosis is directly related to a drop in the serum estrogen level, and it is an important cause of morbidity and mortality [2].
Reproductive factors, such as the number of parities, age at menarche and menopause, duration of menopause, duration of breast-feeding, and intervals between pregnancies, affect bone mineral density (BMD) [3, 4]. In addition, epidemiologically, osteoporosis has been associated with athero-

Received: March 28, 2017 Accepted: August 04, 2017 Online: October 24, 3027

Correspondence: Dr. Dogan VATANSEVER. Semsi Denizer Caddesi, E-5 Karayolu Cevizli Mevkii, Kartal, Istanbul, Turkey Tel: +90 2164413900 e-mail: doganvatansever@yahoo.com

(c) Copyright 2017 by Istanbul Northern Anatolian Association of Public Hospitals - Available online at www.kuzeyklinikleri.com 
sclerosis and hyperlipidemia [5]. Parhami et al. [6] revealed the effects of cholesterol and its metabolites on osteoblastic activity in in vivo and in vitro settings. In addition, they detected a dose-dependent increase in alkaline phosphatase activity, which is an indicator of osteoblastic differentiation [6, 7]. Buizert et al. [8] evaluated the correlation between cardiovascular disease and osteoporosis, and reported that lipid profile parameters known to have a protective role against cardiovascular disease, such as high-density lipoprotein (HDL) and a low total cholesterol (TC)/ HDL ratio, did not inhibit osteoporosis. The plasma atherogenic index (PAI), related to the size of HDL cholesterol particles and low-density lipoprotein (LDL) and the esterification of cholesterol, also reflects the risk of coronary artery atherosclerosis and cardiovascular risk, and improves the overall evaluation of cardiovascular risk factors [9]. Atherogenic lipid levels change with menopause.

In this study, the aim was to investigate the correlation between lipid profile, PAI, and osteoporosis in women.

\section{MATERIALS AND METHODS}

This retrospective investigation was performed with a total 407 postmenopausal women aged between 45 and 80 years of age who had not been menstruating for $\geq 12$ months and who presented at the outpatient clinic of obstetrics and gynecology. The study protocol was approved by the ethics committee of Kartal Dr. Lütfi Kırdar Training and Research Hospital. Patients who were receiving hormone replacement therapy and/or drugs that could affect bone metabolism or lipid profile; and those with hepatic, renal, or cardiac disease were excluded from the study. Age, duration of menopause, height, body weight, lipid profile, $B M D$ value, and oral contraceptive (OCS) use were recorded. Body mass index (BMI) was calculated as the ratio between body weight and height expressed as $\mathrm{kg} / \mathrm{m}^{2}$ [10]. PAI was calculated as the logarithm of triglyceride (TG)/HDL cholesterol ratio. BMD of the lumbar region (L2-4) and femoral neck was measured and recorded. BMD values were divided into 2 categories: normal (T-score $\geq 1 \mathrm{SD}$ ), and osteoporotic (T-score $\leq 2.5 \mathrm{SD}$ ) [11]. Patients with a normal
T score constituted the control group. In our laboratory, the respective normal reference ranges were TC: 100-200 mg/dL, TG: 50-200 mg/dL,HDL: $45 \mathrm{mg} /$ $\mathrm{dL}$, and LDL cholesterol $\leq 129 \mathrm{mg} / \mathrm{dL}$.

\section{Statistical analysis}

SPSS Statistics for Windows, Version 17.0. (SPSS Inc., Chicago, IL, USA) was used to analyze the data. The distribution characteristics of the data were determined using the Kolmogorov-Smirnov test. An independent samples $\mathrm{t}$-test was used for the data with a normal distribution, and the Mann-Whitney $\mathrm{U}$ test was applied to the data with non-normal distribution. Numerical variables were presented as mean \pm SD. The results were evaluated within a $95 \%$ confidence interval. A $p$ value of $<0.05$ was considered to be statistically significant.

\section{RESULTS}

All of the study participants were postmenopausal women aged 45 to 80 years. Among them, 144 women with a mean age of $61.7 \pm 6.9$ years were osteoporotic. The control group consisted of 263 cases without osteoporosis, and the mean age was $58.3 \pm 4.5$ years. The mean duration of menopause was $13.58 \pm 7.61$ years in the osteoporotic group, and $8.53 \pm 4.48$ years in the control group.

BMI values were significantly higher in the control group relative to the osteoporotic group $(27.8 \pm 4.1$ vs. $\left.25.2 \pm 3.3 \mathrm{~kg} / \mathrm{m}^{2} ; \mathrm{p}<0.001\right)$. No significant difference was detected between the osteoporotic and control group in OCS use $(\mathrm{p}=0.728)$.

TC values in the control group were significantly higher $(p=0.002)$. LDL $(p=0.01)$ values were also comparatively higher in the control group, while HDL values were significantly lower $(\mathrm{p}<0.001)$. PAI values were found to be significantly lower in the patients with osteoporosis $(\mathrm{p}=0.032)$ (Table 1 ).

\section{DISCUSSION}

The primary objective of this study was to evaluate the relationship between osteoporosis and PAI. In addition, the BMI, TC, LDL, HDL, and use of 
TABLE 1. The demographic characteristics, lipid profile and plasma atherogenic index values of the patients

\begin{tabular}{lccc} 
& $\begin{array}{c}\text { Control } \\
(\mathrm{n}=263)\end{array}$ & $\begin{array}{c}\text { Osteoporosis } \\
(\mathrm{n}=144)\end{array}$ & $\mathrm{p}$ \\
\hline Age (years) & $58.3 \pm 4.5$ & $61.7 \pm 6.9$ & $<0.001$ \\
BMI $\left(\mathrm{kg} / \mathrm{m}^{2}\right)$ & $27.8 \pm 4.1$ & $25.2 \pm 3.3$ & $<0.001$ \\
Duration of menopause (years) & $9.1 \pm 4.4$ & $13.5 \pm 7.6$ & $<0.001$ \\
Duration of OCS use (months) & $9.6 \pm 23.4$ & $10.7 \pm 41.2$ & 0.728 \\
LDL (mg/dL) & $137.7 \pm 34.8$ & $128.5 \pm 36.3$ & 0.010 \\
Triglyceride (mg/dL) & $131.1 \pm 50.7$ & $128 \pm 46.3$ & 0.762 \\
HDL (mg/dL) & $50.1 \pm 10.6$ & $54.8 \pm 11.3$ & $<0.001$ \\
Total cholesterol (mg/dL) & $222 \pm 43.7$ & $208.2 \pm 38.5$ & 0.002 \\
PAI & $0.39 \pm 0.2$ & $0.34 \pm 0.1$ & 0.032 \\
\hline
\end{tabular}

Data are presented as mean \pm SD.

BMI: Body mass index; HDL: High-density lipoprotein; LDL: Low-density lipoprotein; OCS: Oral contraceptive, PAI: Plasma atherogenic index.

OCS were evaluated. In the osteoporotic group, the PAI, BMI, LDL, and TC levels were lower, but HDL was higher than in the control group. TG and OCS levels did not demonstrate a significant intergroup difference. Obesity may help maintain BMD with a reactive increase in bone formation and mineral density. Therefore, higher atherogenic lipid levels and PAI values are anticipated in obese patients, which is consistent with our results.

The rate of dyslipidemia increases after menopause [12]. Increases in TC, LDL, and TG levels have been demonstrated; however, HDL data have been controversial. Some authors indicated a lack of any change in HDL values [13-16], while others have reported decreased [17-19] or increased HDL levels [20]. The PAI measurement is a logarithmic transformation of the TG/HDL-cholesterol ratio, and was introduced by Dobiasova et al. [9]. PAI also demonstrates a negative correlation with the particle size of LDL cholesterol. In a study conducted by Söğüt et al. [21], PAI was demonstrated to be the most robust biochemical parameter in the prediction of coronary heart disease.

In our study, TG values did not differ significantly between groups; however, HDL levels were statistically significantly different. This finding suggests that an increased HDL level in the osteoporotic group in- duced a drop in PAI, which may be correlated with bone metabolism. The impact of HDL on BMD is not precisely known [8]. Studies that have evaluated the relationship between HDL and BMD have yielded different results $[22,23]$. In a few studies, a negative correlation was detected, as in the present study [24-29]. However, in epidemiological studies performed, type 2 diabetic patients with lower HDL levels have been associated with increased BMD values [30-33]. Furthermore, in the large, population-based Tromso study in which 27.159 patients were followed up for 6 years, a protective effect of lower HDL values against non-vertebral fractures was demonstrated [31]. PAI is a strong risk factor for cardiovascular disease. Anti-inflammatory, antioxidant, antithrombotic, and cholesterol transporter functions of the HDL component of PAI have been also been reported [34-36]. In recent years, because of its HDL-cholesterol promoting effects, the importance of developing PAI-lowering treatments has been emphasized. These drugs, in combination with cholesterol-lowering drugs, may be an effective treatment alternative for cardiovascular disease. However, this approach revives the dilemma concerning whether or not HDL-increasing drugs will eliminate the protective effect of HDL on non-vertebral fractures. $[34,35]$. Since osteoporosis and the related 
bone fractures are among the most important health problems of our aging population, the association between HDL and BMD should be further explored.

Previously, TC was thought to be associated with cardiovascular diseases and osteoporosis, and consequently, studies investigating the correlation between TC and BMD were performed. However, these studies yielded various outcomes. Some found no relationship between the two $[37,38]$, while others reported a positive $[24,39]$ or negative correlation [40]. In our study, TC levels were higher in the control group compared with the osteoporotic group.

In conclusion, the present study demonstrated that high HDL and low LDL and PAI levels, which are important in the prevention of cardiovascular diseases, are negative factors for BMD. However, to demonstrate the pathophysiological relationship between lipid profile and BMD, and to substantiate our results, larger-scale studies are needed.

Conflict of Interest: No conflict of interest was declared by the authors.

Financial Disclosure: The authors declared that this study has received no financial support.

Authorship contributions: Concept - G.Ş.E., E.E.Ş., D.V., H.Ö.K., B.K., Ö.S.; Design - G.Ş.E., E.E.Ş., D.V., H.Ö.K., B.K., Ö.S.; Supervision - G.Ş.E., E.E.Ş., D.V.; Materials - G.Ş.E., E.E.Ş.; Data collection \&/or processing - G.Ş.E., E.E.Ş., D.V.; Analysis and/or interpretation - G.Ş.E., E.E.Ş.; Literature search - E.E.Ş., D.V.; Writing - G.Ş.E., E.E.Ş.; Critical review G.Ş.E., E.E.Ş., D.V., H.Ö.K., B.K.

\section{REFERENCES}

1. Kenny AM, Prestwood KM. Osteoporosis, pathogenesis, diagnosis and treatment in older adults. Rheum Dis Clin N Am 2000;26:569-91. [CrossRef]

2. Lindsay R. Sex steroids in the pathogenesis and prevention of osteoporosis. In: Riggs BL, Melton LJ, ed. 1988 Osteoporosis: etiology, diagnosis, and management. New York: Raven Press; p.333-58.

3. Bolzetta F, Veronese N, De Rui M, Berton L, Carraro S, Pizzato $\mathrm{S}$, et al. Duration of breastfeeding as a risk factor for vertebral fractures. Bone 2014;68:41-5. [CrossRef]

4. Sahin Ersoy G, Giray B, Subas S, Simsek E, Sakin O, Turhan OT, et al. Interpregnancy interval as a risk factor for postmenopausal osteoporosis. Maturitas 2015;82:236-40. [CrossRef]

5. Tintut Y, Morony S, Demer LL. Hyperlipidemia promotes osteoclastic potential of bone marrow cells ex vivo. Arterioscler Thromb Biol 2004;24:6-10. [CrossRef]
6. Parhami F, Garfinkel A, Demer LL. Role of lipids in osteoporosis. Arterioscler Thromb Vasc Biol 2000;20:2346-8. [CrossRef]

7. Tanko LB, Christiansen C, Cox DA, Geiger MJ, McNabb MA, Cummings SR. Relationship between osteoporosis and cardiovascular disease in postmenopausal women. J Bone Miner Res 2005;20:1912-20. [CrossRef]

8. Buizert PJ, van Schoor NM, Lips P, Deeg DJ, Eekhoff EM. Lipid levels: a link between cardiovascular disease and osteoporosis? J Bone Miner Res 2009;24:1103-9. [CrossRef]

9. Dobiásová M, Frohlich J. The plasma parameter log (TG/ HDLC) as an atherogenic index: Correlation with lipoprotein particle size and esterification rate in apoB-lipoprotein-depleted plasma [FER (HDL)]. Clin Biochem 2001;34:583-8. [CrossRef]

10. Rolland-Cachera MF, Cole TJ, Sempe M. Body mass index variations: centiles from birth to 87 years. Eur J Clin Nutr 1991;45:13-21.

11. Link TM, Majumdar S. Osteoporosis imaging. Radio Clin N Am 2003;41:813-839. [CrossRef]

12. Ramos RG, Olden K. The prevalence of metabolic syndrome among US women of childbearing age. Am J Public Health 2008;98:1122-7. [CrossRef]

13. Davis CE, Pajak A, Rywik S, Williams DH, Broda G, Pazucha $T$, et al. Natural menopause and cardiovascular disease risk factors. The Poland and US Collaborative Study on Cardiovascular Disease Epidemiology. Ann Epidemiol 1994;4:445-8. [CrossRef]

14. Brown SA, Hutchinson R, Morrisett J, Boerwinkle E, Davis CE, Gotto AM Jr, et al. Plasma lipid, lipoprotein cholesterol, and apoprotein distributions in selected US communities. The Atherosclerosis Risk in Communities (ARIC) Study. Arterioscler Thromb 1993;13:1139-58, [CrossRef]

15. Demirovic J, Sprafka JM, Folsom AR, Laitinen D, Blackburn H. Menopause and serum cholesterol: differences between blacks and whites. The Minnesota Heart Survey. Am J Epidemiol 1992;136:155-64. [CrossRef]

16. Bonithon-Kopp C, Scarabin PY, Darne B, Malmejac A, Guize L. Menopause-related changes in lipoproteins and some other cardiovascular risk factors. Int J Epidemiol 1990;19:42-8.

17. Poehlman ET, Toth MJ, Ades PA, Rosen CJ. Menopause- associated changes in plasma lipids, insulin-like growth factor I and blood pressure: a longitudinal study. Eur J Clin Invest 1997;27:322-6. [CrossRef]

18. Stevenson JC, Crook D, Godsland IF. Influence of age and menopause on serum lipids and lipoproteins in healthy women. Atherosclerosis 1993;98:83-90. [CrossRef]

19. Matthews KA, Meilahn E, Kuller LH, Kelsey SF, Caggiula AW, Wing RR. Menopause and risk factors for coronary heart disease. N Engl J Med 1989;321:641-6. [CrossRef]

20. Wu ZY, Wu XK, Zhang YW. Relationship of menopausal status and sex hormones to serum lipids and blood pressure. Int J Epidemiol 1990;19:297-302. [CrossRef]

21. Sögüt E, Avcı E, Üstüner F, Arıkan E. The Evaluation of (TG/ HDL-C) Ratio as a Serum Atherogenic Index. Türk Klinik Biyokimya Derg 2006;4:1-8. 
22. Yild $1 z$ C, Y1ld $1 z$ A, Tekiner F. Comparison of serum lipid profile and plasma atherogenic index between premenopausal and postmenopausal women. Dicle Med J 2015;42:36-40.

23. Jeong IK, Cho SW, Kim SW, Choi HJ, Park KS, Kim SY. Lipid profiles and bone mineral density in pre- and postmenopausal women in Korea. Calcif Tissue Int 2010;87:507-12. [CrossRef]

24. Adami S, Braga V, Zamboni M, Gatti D, Rossini M, Bakri J, et al. Relationship between lipids and bone mass in 2 cohorts of healthy women and men. Calcif Tissue Int 2004;74:136-42.

25. D’Amelio P, Pescarmona GP, Gariboldi A, Isaia GC. High density lipoproteins (HDL) in women with postmenopausal osteoporosis: A preliminary study. Menopause 2001;8:429-32.

26. Lidfeldt J, Holmdahl L, Samsioe G, Nerbrand C, Nyberg P, Schersten B, et al. The influence of hormonal status and features of the metabolic syndrome on bone density: A population-based study of Swedish women aged 50 to 59 years. The women's health in the Lund area study. Metabolism 2002;51:267-70.

27. Zabaglia SF, Pedro AO, Pinto Neto AM, Guarisi T, Paiva LH, Lane E. An exploratory study of the association between lipid profile and bone mineral density in menopausal women in a Campinas reference hospital. Cad Saude Publica 1998;14:779-86.

28. Adami S, Braga V, Gatti D. Association between bone mineral density and serum lipids in men. JAMA 2001;286:791-2.

29. Dennison EM, Syddall HE, Aihie SA, Martin HJ, Cooper C. Lipid profile, obesity and bone mineral density: The Hertfordshire Cohort Study. QJM 2007;100:297-303. [CrossRef]

30. Gerdhem P, Isaksson A, Akesson K, Obrant KJ. Increased bone density and decreased bone turnover, but no evident alteration of fracture susceptibility in elderly women with diabetes mellitus. Osteoporos Int 2005;16:1506-12. [CrossRef]

31. Ahmed LA, Schirmer H, Berntsen GK, Fonnebo V, Joakimsen RM. Features of the metabolic syndrome and the risk of non-vertebral fractures: The Tromso study. Osteoporos Int
2006;17:426-32. [CrossRef]

32. Vestergaard P. Discrepancies in bone mineral density and fracture risk in patients with type 1 and type 2 diabetes-a meta-analysis. Osteoporos Int 2007;18:427-44. [CrossRef]

33. Pérez-Castrillón JL, De Luis D, Martín-Escudero JC, Asensio T, del Amo R, Izaola O. Non-insulin-dependent diabetes, bone mineral density, and cardiovascular risk factors. J Diabetes Complications 2004;18:317-21. [CrossRef]

34. Chapman MJ. Therapeutic elevation of HDL-cholesterol to prevent atherosclerosis and coronary heart disease. Phar-macol Ther 2006;111:893-908. [CrossRef]

35. Birjmohun RS, van der Steeg WA, Stroes ES, Kastelein JJ. The role of the high-density lipoprotein (HDL) particle in atherogenesis and potential methods to increase HDL concentrations. Ned Tijdschr Geneeskd 2006;150:2245-50.

36. Noor R, Shuaib U, Wang CX, Todd K, Ghani U, Schwindt B, et al. High-density lipoprotein cholesterol regulates endothelial progenitor cells by increasing eNOS and preventing apoptosis. Atherosclerosis 2007;192:92-9. [CrossRef]

37. Yamaguchi T, Sugimoto T, Yano S, Yamauchi M, Sowa H, Chen $\mathrm{Q}$, et al. Plasma lipids and osteoporosis in postmenopausal women. Endocr J 2002;49:211-7. [CrossRef]

38. Samelson EJ, Cupples LA, Hannan MT, Wilson PW, Williams SA, Vaccarino V, et al. Long-term effects of serum cholesterol on bone mineral density in women and men: The Framingham Osteoporosis Study. Bone 2004;34:557-61. [CrossRef]

39. Brownbill RA, Ilich JZ. Lipid profile and bone paradox: Higher serum lipids are associated with higher bone mineral density in postmenopausal women. J Womens Health (Larchmt) 2006;15:261-70. [CrossRef]

40. Tanko LB, Bagger YZ, Nielsen SB, Christiansen C. Does serum cholesterol contribute to vertebral bone loss in post-menopausal women. Bone 2003;32:8-14. [CrossRef] 